\author{
Paulina Borowczyk \\ Uniwersytet im. Adama Mickiewicza w Poznaniu
}

\title{
TEORIA SKOPOSU A ROLA TŁUMACZA-DIALOGISTY W FILMACH DUBBINGOWANYCH
}

\begin{abstract}
Zarys treści: W niniejszym artykule skupiam się na roli tłumacza-dialogisty w filmach dubbingowanych, którą porównuję do roli łłumacza w teorii skoposu (niem. Skopostheorie), czyli podejścia propagującego funkcjonalną teorię przekładu. Opierając się na założeniu, że tłumaczenie jest aktem międzykulturowym oraz biorąc pod uwagę potrzeby odbiorcy oraz funkcję, jaką dany film ma spełniać w kulturze docelowej, tłumacz filmów dubbingowanych tworzy przekład funkcjonalny względem oryginału. Aby osiągnąć zamierzony cel w tłumaczonych dialogach na języki docelowe, tłumacze stosują tzw. lokalizację, czyli przekładają rozmaite sytuacje kulturowe i żarty na lokalne realia.
\end{abstract}

Słowa kluczowe: teoria skoposu; tłumaczenie audiowizualne; lokalizacja

$\mathrm{N}^{2}$ akręcone w ostatnich latach globalne hity kinowe, animowane bądź z udziałem aktorów, w większości amerykańskie (ale również francuskie), kreujące bajkowy lub historyczno-baśniowy świat, w którym znaleźli się główni bohaterowie, przyciągają i bawią bardzo zróżnicowaną publiczność, a każda grupa wiekowa uruchamia własne ścieżki interpretacyjne warstw wizualnej i werbalnej. Do czynników, które bezpośrednio składają się na sukces takich filmów jak m.in. Shrek (2001), Shrek 2 (2004), Potwory i spółka (2001), Epoka lodowcowa (2002), Asterix i Obelix: Misja Kleopatra (2002), Madagaskar (2005), Asterix na olimpiadzie (2008), należą przede wszystkim absurdalny humor oraz postmodernistyczny charakter animowanych opowieści, w których „nie ma miejsca na ckliwość, sentymentalizm i dydaktykę, sporo [w nich] natomiast kpiny, ironii i wręcz szyderstwa” (Zarębski 2001: 46), a tradycyjne wartości ulegają przewartościowaniu. Ponadto producenci fil- 
mowi zadbali o to, by stworzyć całą siatkę aluzji, nawiązań i odwołań do świata popkultury, do znanych filmów, dzieł literackich czy współczesnych postaci zarówno w warstwie wizualnej (np. w formie parodii scen pochodzących z innych filmów, pojawiających się na ekranie postaci z innych bajek czy logo, symboli i szyldów firm o zasięgu międzynarodowym lub narodowym), jak i słownej (np. w formie wplecionych w dialogi oryginalnych bądź zmodyfikowanych na potrzeby filmu cytatów) lub też w obydwu kanałach jednocześnie. Kolejną mocną stroną wyżej wymienionych filmów są świetnie wykonany dubbing oraz doborowe towarzystwo aktorów użyczających swoich głosów poszczególnym bohaterom $\mathrm{w}$ różnych wersjach językowych. I wreszcie ostatnim, ale nie mniej istotnym czynnikiem są bardzo dobrze napisane, naturalnie brzmiące dialogi, w których dominuje użycie języka potocznego, nieformalnego. Jak słusznie zauważa Belczyk,

jedna z podstawowych zasad translatorskich głosi, że aby przekład nie był postrzegany przez odbiorcę jako coś obcego, irytującego sztucznością, powinien naśladować analogiczne teksty funkcjonujące w języku docelowym, ich charakterystyczną stylistykę i frazeologię. Dla dialogów filmowych taki oczywisty wzorzec stanowi polszczyzna mówiona: w polskim tłumaczeniu bohaterowie muszą mówić językiem, jakiego w identycznych sytuacjach najprawdopodobniej użyliby Polacy (2007: 39),

bądź wykreowane przez scenarzystów postacie analizowanych filmów, których reakcje i zachowania są takie same jak u ludzi. Dodatkowo, oryginalne dialogi obfitują w odniesienia do kultury wyjściowej, ich przekłady zaś - w elementy nawiązujące do zjawisk z rodzimego zaplecza kulturowego.

Mając na uwadze fakt, że w komunikatach audiowizualnych tłumacz nie ingeruje w nienaruszalną część wizualną dzieła filmowego, musi on w swojej pracy wziąć pod uwagę efekt, jaki tego rodzaju filmy mają wywołać u odbiorców, jak i samą publiczność i jej potrzeby. Jego zadaniem jest stworzenie przekładu funkcjonalnego względem oryginału (Garcarz 2007: 120). Jak zauważa Urbańska, tłumacze dialogów w dubbingowanych filmach używają całej gamy różnorodnych środków w celu osiągnięcia pełnej ekwiwalencji pragmatycznej.

W praktyce oznacza to, iż obie wersje językowe (oryginalna i polska) powinny wywoływać ten sam efekt komunikacyjny na odbiorcach. Rosnąca popularność dubbingowanych filmów animowanych w Polsce może świadczyć o tym, iż twórcy polskich dialogów zamierzony efekt osiągają (Urbańska, Dla kogo...). 
W konsekwencji widzowie mogą czasem odnieść wrażenie, że film jest osadzony w rzeczywistości, którą dobrze znają, i że jest adresowany właśnie do nich. Jak wynika z moich badań i analiz dialogów filmowych, odpowiadając na potrzeby odbiorcy, tłumacz tworzy w języku docelowym dialogi charakteryzujące się dużą naturalnością, swojskością oraz przede wszystkim łatwością w recepcji. I tu dochodzimy do sedna współczesnego podejścia do przekładu filmów dubbingowanych: ma być śmiesznie, a nie wiernie. Zdaniem Bartosza Wierzbięty, jednego z polskich tłumaczy filmów animowanych, który tych tłumaczeń na swoim koncie ma najwięcej,

wierność w przekładzie nie sprowadza się do używania słownikowych odpowiedników, tylko utrzymania bilansu, który się zachowuje na poziomie odbioru. W komedii nie chodzi przecież o siłową grę słów - bo może być wtedy żałosna albo niezrozumiała. A ma być śmieszna (Baryłkiewicz on-line).

Fakt odwoływania się do rodzimej rzeczywistości budzi jednak kontrowersje. Jak zauważa Janusz Wróblewski,

tych odniesień do polskiej sztuki i do polskiej rzeczywistości jest zresztą tyle, że czasami traci się poczucie, że oglądany film został zrealizowany przez nie-Polaka. Przykładowo, jeśli jeden z bohaterów Asterixa odzywa się do drugiego: „Zdrastwujcie, którędy do Galów??. I słyszy odpowiedź: „Prosto, jak w mordę strzelił”, to czujemy się jak w domu. Co my właściwie oglądamy? Zagraniczny film w polskim tłumaczeniu czy polską wersję zagranicznego filmu? [...] Przynajmniej od premiery Shreka problem literackiej wierności przekładu filmowych dialogów przestał być aktualny (Wróblewski 2002: 53).

Prawdą jest, że czasem trudno zaklasyfikować polskie wersje dialogów jako wierne tłumaczenia. Wierność przekładu to, jak zauważają teoretycy przekładu (m.in. Amparo Hurtado Albir, Jean Delisle, Hannelore Lee-Jahnke i in.), jedno z pojęć najtrudniej definiowalnych i budzących najwięcej polemik.

Kryteria służące ocenie wierności tłumaczenia danego tekstu zależą od wielu parametrów, wśród których można wymienić: cele tłumacza, przyjętą strategię tłumaczenia, rodzaj omawianej w tekście problematyki, dokładność przekazywanych informacji, gatunek tekstu, funkcje i zastosowanie danego tekstu, jego czułe punkty, jego tekstowość, jego wartości literackie, kontekst społeczno-historyczny, sposób przyjęcia tekstu przez odbiorców, normy, świat pojęć (Delisle, Lee-Jahnke, Cormier 2004: 117). 
Przez pryzmat jakich parametrów należy zatem oceniać wierność tłumaczonych dialogów w filmach dubbingowanych? Czy wierność przekładu $\mathrm{w}$ takich produkcjach nie będzie sprawą otwartą i względną, mając na uwadze aspekty pragmatyczne i komunikacyjne filmu, jego cele, zamierzone efekty i adresatów? Nadrzędnym celem tego rodzaju produkcji (w których liczy się przede wszystkim szybkość i łatwość odbioru komunikatu) jest wywołanie konkretnych reakcji u widzów. Mając do czynienia z komedią, w której humor jest wyrażony za pomocą aluzji i odwołań do własnego zaplecza kulturowego znanego odbiorcom oryginału, lecz niezrozumiałego dla odbiorców tłumaczonych dialogów, tłumacz-dialogista może, z powodu braku odpowiednika w języku i kulturze docelowej dla elementu typowego dla kultury oryginału, rekompensować ten brak innymi efektami, wywołującymi śmiech. Sposobem na osiągnięcie takiej reakcji, są m.in. odnośniki do rodzimej rzeczywistości, ale również użycie kolokwialnych wyrażeń czy szyku przestawnego. I jeśli scenariusz filmu jest wytworem wyobraźni scenarzysty i abstrahuje od rzeczywistości, a tłumacz nie ingeruje $\mathrm{w}$ treści do przekazania ani nie zmienia rysu psychologicznego bohaterów, to zabawa w skojarzenia $\mathrm{z}$,własnego podwórka" jest w pełni uzasadniona. Zresztą na tym właśnie polega dubbing - to jedno wielkie oszustwo. „To jakby próba wmówienia, że film był zrobiony w Polsce. Chodzi o to, żeby złudzenie było możliwie przekonujące" (Wierzbięta, Kojarzę się...).

Dubbing polega na tym, że dużą część filmu robi się od nowa. W filmie najważniejsi są aktorzy, jeśli zmienimy aktorów - zmieniamy prawie cały film. I nie ma już sensu kurczowe trzymanie się oryginału. [...] W dubbingu dbamy o zachowanie bilansu emocjonalnego - żeby śmiechu i wzruszeń było tyle samo i w tych samych momentach (Wierzbięta 2004: 11).

Działania tłumacza zmierzające do osiągnięcia złudzenia, że oryginał nie istniał, mają na celu ułatwić odbiór filmu grupie docelowej. Ponadto dowodem na to, że dubbingowane dialogi są coraz bardziej odległe od tradycyjnego tłumaczenia jest fakt, że współcześni tłumacze-dialogiści nie są proszeni o przetłumaczenie scenariusza, tylko o dokonanie dynamicznej, twórczej adaptacji do filmu (Baryłkiewicz on-line), a ich zadaniem jest osiągnięcie efektu komunikacyjnego.

Obserwując takie podejście tłumaczy-dialogistów do przekładu, można odwołać się do niemieckiej szkoły tłumaczenia stworzonej przez Katharinę Reiss oraz Hansa Josefa Vermeera (1984), propagującej funkcjonalną teorię przekładu (niem. Skopostheorie). Warto nadmienić, że inna niemiecka ba- 
daczka - Christiane Nord (2009) znacząco rozbudowała i „dokonała twórczej interpretacji stworzonej przez Reiss i Vermeera teorii skoposu" (Bukowski 2009: 173). Według Christiane Nord,

teoria ta opisuje tłumaczenie (translację) jako celową czynność, przy czym orientacja na cel, jakiemu służyć ma przekład, stanowi najważniejsze kryterium jej fortunnej realizacji (Nord 2009: 175-176).

Opierając się na założeniu, że tłumaczenie nie jest operacją czysto międzyjęzykową, ale przede wszystkim aktem międzykulturowym, oraz biorąc pod uwage potrzeby odbiorcy oraz cel (skopos)/funkcję, jaką dany film ma spełniać w kulturze docelowej, tłumacz filmów dubbingowanych tworzy przekład funkcjonalny względem pierwotnych dialogów.

$\mathrm{Z}$ jednej strony tłumacz według tej teorii jest centralnym podmiotem przekładu, jako że ma on pełną swobodę w dobieraniu środków stylistycznego wyrazu w języku przekładu. Struktura i forma, jaką przybiera tekst przekładu, schodzi na plan dalszy, gdyż liczy się tylko jego funkcjonalność [...]. Z drugiej strony tłumacz może być widziany jako przedmiot aktu komunikacyjnego, jakim jest przekład, gdyż określając cel, czyli właśnie skopos [...], jaki ma spełniać tekst docelowy, tłumacz kieruje się potrzebami odbiorcy, czyli staje się od tego odbiorcy „zależny” niczym zleceniobiorca względem zleceniodawcy (Garcarz 2007: 120).

W praktyce oznacza to, że tłumacz jest świadomy, jaki cel ma zostać osiągnięty za pomocą tekstu docelowego, i dlatego w procesie tłumaczenia może posłużyć się innymi środkami, a nawet treściami, by w umyśle odbiorcy wywołać podobne lub takie same skojarzenia jak u widza oryginalnej wersji filmu (Nord 2009: 179). I właśnie posługując się techniką adaptacji (zwanej również ekwiwalentem funkcjonalnym) lub zwyczajnie zawierzając własnej inwencji, wyobraźni i kreatywności, tłumacz może z powodzeniem odwołać się do wiedzy encyklopedycznej odbiorców tekstu docelowego, by wywołać podobne reakcje jak u odbiorców oryginału. Aby dany element kulturowy czy gra słów mogły zostać rozpoznane i zrozumiane, „szczególnie istotne staje się dopasowanie ich do norm i konwencji kultury docelowej" (Nord 2009: 189). Jeśli tłumacz tego nie zrobi, to ze względu na dystans kulturowy pozostawienie w tekście docelowym elementu właściwego oryginałowi „wywołałoby u odbiorcy przekładu efekt obcości niezamierzony przez autora” (Nord 2009: 183). Zatem w omawianych produkcjach, zagadnienie wierności przekładu względem sensu oryginału należy rozpatrywać zarówno przez pryzmat celo- 
wości filmów i funkcji, jaką będą pełnić w kulturze docelowej, jak i z punktu widzenia odbiorcy przekładu, który ma ten sens zrozumieć. Ponadto w komunikatach audiowizualnych, w których widz nie ma możliwości ponownego usłyszenia dialogów, powrotu do poprzedniej sceny czy też nie ma czasu na głębszą analizę treści dialogów, sens musi być zrozumiany natychmiastowo. Aluzje z „własnego podwórka” widz wychwyci i zrozumie błyskawicznie.

Odwołując się do typologii tłumaczeń sporządzonej przez Barbarę Walkiewicz, można stwierdzić, że tłumaczenie dialogów w filmach dubbingowanych, zwłaszcza na poziomie makrostruktury, należy do „tłumaczeń heteromorficznych ekwifunkcjonalnych" (Walkiewicz 2013: 56-58).

W tego typu przekładach zamierzony cel tekstu docelowego ma być zbieżny z efektem komunikacyjnym przyświecającym oryginałowi, w związku z czym tłumacz jako podmiot komunikacyjny II stopnia stara się wyeliminować ślady swojej interwencji [...], starając się osiągnąć maksymalną zgodność tłumaczenia z dyskursywnie uwarunkowanymi oczekiwaniami podmiotu interpretującego II stopnia, czyli odbiorcy tekstu docelowego (Walkiewicz 2013: 56).

Jak zaznacza dalej Walkiewicz,

z tłumaczeniem omawianego typu mamy do czynienia w sytuacji nadrzędności funkcji, której w określonej mierze podporządkowana jest forma: przy założeniu inwariantu, jakim jest zamierzenie autora (funkcja), tłumacz dobiera formę optymalnie przekazującą informację wyjściową, aby uzyskać cel komunikacyjny zbieżny z celem założonym w oryginale (Walkiewicz 2013: 57).

W przypadku filmów dubbingowanych, w których nadrzędnym i globalnym celem jest wywołanie konkretnego efektu u widzów (śmiech), aby pokonać dystans kulturowy, który dzieli odbiorcę dialogów oryginału oraz odbiorcę tłumaczonych dialogów i osiągnąć efekt komunikacyjny porównywalny z celem założonym w oryginale (efekt komiczny), tłumacze stosują tzw. lokalizację, czyli przekładają sytuacje kulturowe typowe dla cywilizacji wyjściowej na lokalne realia znane odbiorcom wersji docelowej bądź wprowadzają do tekstu docelowego odnośniki do rodzimej rzeczywistości, nawet jeśli nie było ich w oryginale (technika kompensacji). Ponadto, jak zostało już wspomniane powyżej, z uwagi na wielokodowość przekazu audiowizualnego tłumacz ma możliwość ingerencji wyłącznie w warstwę werbalną filmu, nie modyfikując ani nie naruszając warstwy wizualnej, która również jest naszpikowana aluzjami kulturowymi, np. w postaci podobieństw fizycznych, mimiczno-gesty- 
kulacyjnych bohaterów pojawiających się na ekranie do znanych osobowości za świata mediów. $Z$ tego względu, mówiąc o tłumaczeniu heteromorficznym ekwifunkcjonalnym odwołujemy się wyłącznie do przekładu dialogów. Natomiast niektóre obrazy nie będą pełnić zamierzonych przez twórców filmu funkcji w kulturze docelowej (np. polskiej, francuskiej czy niemieckiej) ze względu na brak ich właściwego odkodowania (por. Borowczyk 2013).

Przyjrzyjmy się konkretnym przykładom zaczerpniętym z dialogów filmowych.

\begin{tabular}{|c|c|c|c|}
\hline $\begin{array}{c}\text { Wersja angielska } \\
\text { (TW) }\end{array}$ & $\begin{array}{l}\text { Wersja francuska } \\
\text { (TD1) }\end{array}$ & $\begin{array}{l}\text { Wersja niemiecka } \\
\text { (TD2) }\end{array}$ & $\begin{array}{l}\text { Wersja polska } \\
\text { (TD3) }\end{array}$ \\
\hline $\begin{array}{l}\text { Fairy Godmother: } \\
\text { Jerome! Coffee and } \\
\text { Monte Cristo, now! } \\
\text { Receptionist: Yes, } \\
\text { Fairy Godmother. } \\
\text { Right away. }\end{array}$ & $\begin{array}{l}\text { Marraine la Fée: } \\
\text { Jérôme! Espresso et } \\
\text { un Monte Cristo, } \\
\text { presto! } \\
\text { Le réceptionniste: } \\
\text { Ah! Oui, Marraine la } \\
\text { Bonne Fée. Je viens } \\
\text { tout de suite. }\end{array}$ & $\begin{array}{l}\text { Der Gute Fee: } \\
\text { Jerome! Kaffee und } \\
\text { ein Monte Cristo } \\
\text { Sandwich, aber dalli! } \\
\text { Empfangschef: Ja, } \\
\text { sehr wohl, gute Fee. } \\
\text { Tout de suite. }\end{array}$ & $\begin{array}{l}\text { Wróżka Chrzestna: } \\
\text { Jean Claude! Kawa } \\
\text { i torcik wedlowski, } \\
\text { ale migiem! } \\
\text { Recepcjonista: } \\
\text { Tak, Pani Dyrektor. } \\
\text { Bezzwłocznie. }\end{array}$ \\
\hline
\end{tabular}

W powyższym przykładzie (Shrek 2) zarówno oryginał, jak i tłumaczenia na języki francuski i niemiecki zawierają ten sam element kulturowy: Monte Cristo, znany odbiorcom z wymienionych kręgów socjokluturowych. Jest to rodzaj kanapek z szynką, plasterkami indyka oraz sera szwajcarskiego, które smaży się na maśle. Ponieważ przekąska nie jest znana polskim odbiorcom, tłumacz zastąpił ją rodzimą słodkością, mianowicie torcikiem wedlowskim.

\begin{tabular}{|c|c|c|c|}
\hline $\begin{array}{l}\text { Wersja angielska } \\
\text { (TW) }\end{array}$ & (TD1) & & $\begin{array}{l}\text { Wersja polska } \\
\text { (TD3) }\end{array}$ \\
\hline $\begin{array}{l}\text { Donkey: It'll be bet- } \\
\text { ter in the morning. } \\
\text { You'll see... The sun'll } \\
\text { come out. Tomorrow. } \\
\text { Bet your bottom... } \\
\text { Shrek: Bet my bot- } \\
\text { tom? } \\
\text { Donkey: } \text { I'm coming, } \\
\text { Elizabeth! }\end{array}$ & $\begin{array}{l}\text { L'Âne: Ça ira mieux } \\
\text { demain matin, tu } \\
\text { verras. The sun'll } \\
\text { come out. Demain } \\
\text { matin. Les gondoles à } \\
\text { Venise. } \\
\text { Shrek: Les gondoles à } \\
\text { Venise? } \\
\text { L'Âne: Ne me quitte } \\
\text { pas! }\end{array}$ & $\begin{array}{l}\text { Esel: Morgen früh } \\
\text { sieht alles besser } \\
\text { aus. Ganz bestimmt. } \\
\text { Verlier nich den Mut. } \\
\text { Denn morgen wird } \\
\text { die Sonne wieder } \\
\text { scheinen. } \\
\text { Shrek: Jeden Tag } \\
\text { etwas Neues. } \\
\text { Esel: Gute Nacht, } \\
\text { John Boy! }\end{array}$ & $\begin{array}{l}\text { Osioł: Jutro będzie } \\
\text { lepiej, zobaczysz. } \\
\text { W czasie deszczu osty } \\
\text { sie nudza. Oj, panie } \\
\text { prosza panów. } \\
\text { Shrek: Panie prosza } \\
\text { panów? } \\
\text { Osioł: } \text { Dlaczego tu } \\
\text { nie ma klamek? }\end{array}$ \\
\hline
\end{tabular}

Kolejny przykład (Shrek 2) w każdej wersji językowej obfituje w odwołania do piosenek i filmów. Chodzi o scenę, w której Shrek, Osioł i Kot 
w Butach po wypiciu magicznego eliksiru chowają się w opuszczonej stajni przed nadciągającą burzą. Shrek tęsknym wzrokiem spogląda w stronę zamku, w którym przebywa jego żona, Fiona. Osioł próbuje go pocieszać. Chwilę później, pod wpływem działania czarodziejskiego eliksiru, Osłu zaczyna się kręcić w głowie, traci przytomność i pada na ziemię, wypowiadając słowa: I'm coming, Elizabeth! W wersji oryginalnej autor odwołuje się do słów bardzo znanej piosenki Tomorrow, śpiewanej przez dziewczynkę o imieniu Annie, główną bohaterkę popularnego w USA musicalu pod tym samym tytułem. Natomiast zdanie zamykające cytowany fragment (I'm coming, Elizabeth!) pochodzi z amerykańskiego sitcomu z lat 70. Sanford and Son. Główny bohater Fred Sanford, często udając atak serca, wołał do swojej zmarłej żony: I'm coming, Elizabeth! We francuskojęzycznych dialogach tłumacz częściowo pozostawił oryginalne słowa amerykańskiej piosenki (The sun'll come out), a następnie zaproponował tytuł znanej we Francji piosenki $\mathrm{z}$ lat 70. Les gondoles à Venise, wykonywanej przez parę kochanków - duet Sheila i Ringo. Na koniec odwołał się do jednej z najbardziej znanych na całym świecie francuskiej piosenki z repertuaru Jacques’a Brela Ne me quitte pas. Jeśli chodzi o tłumaczenie na język niemiecki, to mamy tu do czynienia $\mathrm{z}$ aluzją do wyświetlanego $\mathrm{w}$ wielu krajach na świecie (w tym w Niemczech) bardzo popularnego amerykańskiego serialu telewizyjnego The Waltons $\mathrm{z}$ lat 70. To historia małżeństwa Waltonów i ich siedmiorga dzieci opowiedziana z punktu widzenia najstarszego syna, Johna Boya. Każdy serialowy odcinek kończył się, gdy w domu Waltonów zapadała noc i wszyscy mówili sobie Dobranoc, np. Gute Nacht, John Boy!, Gute Nacht, Jim Bob!, Gute Nacht, Kinder! itd. W polskiej wersji językowej odniesień do rodzimego zaplecza kulturowego jest najwięcej. Pierwszym $\mathrm{z}$ nich jest nawiązanie do tekstu piosenki W czasie deszczu dzieci się nudza z repertuaru Kabaretu Starszych Panów. Następnie, mając na uwadze fakt, że Jerzy Stuhr podkłada swój głos pod postać Osła, tłumacz z powodzeniem nawiązał do ról aktora i wypowiadanych tam przez niego kwestii: Panie prosza panów z filmu Feliksa Falka Wodzirej (1977) oraz Dlaczego tu nie ma klamek? z komedii Juliusza Machulskiego Seksmisja (1984).

Zdarzają się również sytuacje, w których tłumacze-dialogiści wprowadzają elementy typowe dla polskiej rzeczywistości pomimo braku odniesień do kultury wyjściowej w oryginalnej wersji filmu. Oto przykłady kreatywności tłumacza pochodzące z filmu Asterix na olimpiadzie. 


\begin{tabular}{|l|l|l|}
\hline \multicolumn{1}{|c|}{$\begin{array}{c}\text { Wersja francuska } \\
\text { (TW) }\end{array}$} & \multicolumn{1}{|c|}{$\begin{array}{c}\text { Wersja niemiecka } \\
\text { (TD1) }\end{array}$} & \multicolumn{1}{c|}{$\begin{array}{c}\text { Wersja polska } \\
\text { (TD2) }\end{array}$} \\
\hline $\begin{array}{l}\text { Michael Schumacher: Ça } \\
\text { me semble une bonne straté- } \\
\text { gie. On va les battre. }\end{array}$ & $\begin{array}{l}\text { Michael Schumacher: Ist } \\
\text { ne gute Strategie. So gewin- } \\
\text { nen wir. }\end{array}$ & $\begin{array}{l}\text { Michael Schumacher: } \\
\text { Grunt, ze Kubica nie jedzie. } \\
\text { Pokonamy ich. }\end{array}$ \\
\hline
\end{tabular}

W tej scenie niemiecki zawodnik Formuły 1 Michael Schumacher, który rzeczywiście wystąpił w filmie Asterix na olimpiadzie zwraca się do menadżera swojej drużyny Jeana Todta. Obydwie postacie są znane i rozpoznawalne w świecie sportu, zwłaszcza przez fanów wyścigów Formuły 1. W wersjach dubbingowanych filmu wyłącznie polski tłumacz odwołał się dodatkowo do polskiego sportowca, wówczas kierowcy w Formule 1. Fakt, że Schumacher obawiałby się ewentualnego pojedynku z Kubicą, z pewnością wywołuje zamierzony efekt komiczny.

\begin{tabular}{|c|c|c|}
\hline $\begin{array}{c}\text { Wersja francuska } \\
\text { (TW) }\end{array}$ & \multicolumn{1}{|c|}{$\begin{array}{c}\text { Wersja niemiecka } \\
\text { (TD1) }\end{array}$} & $\begin{array}{c}\text { Wersja polska } \\
\text { (TD2) }\end{array}$ \\
\hline Brutus: Faites-le écarteler! & $\begin{array}{l}\text { Brutus: Ihr dürft ihn vier- } \\
\text { teilen! }\end{array}$ & Brutus: Pascal, ugotuj go! \\
\hline
\end{tabular}

Podobnie jak w poprzednim przykładzie, również w tym przypadku wyłącznie polski tłumacz wprowadził do swoich dialogów dodatkowy element. Polscy widzowie nie mają żadnego problemu $\mathrm{z}$ jego odczytaniem. Tłumacz odwołał się bowiem do znanego w Polsce kucharza prowadzącego programy kulinarne w telewizji.

\begin{tabular}{|l|l|l|}
\hline \multicolumn{1}{|c|}{$\begin{array}{c}\text { Wersja francuska } \\
\text { (TW) }\end{array}$} & \multicolumn{1}{|c|}{$\begin{array}{c}\text { Wersja niemiecka } \\
\text { (TD1) }\end{array}$} & \multicolumn{1}{c|}{$\begin{array}{c}\text { Wersja polska } \\
\text { (TD2) }\end{array}$} \\
\hline $\begin{array}{l}\text { Samagas: Brutus, Brutus! } \\
\text { On vous attendait pas si tôt. } \\
\text { Brutus: Ça roulait bien. }\end{array}$ & $\begin{array}{l}\text { Aderlas: Brutus, Brutus! Wir } \\
\text { hatten Euch nicht so bald } \\
\text { erwartet. }\end{array}$ & $\begin{array}{l}\text { Irytos: Brutusie, Brutusie! } \\
\text { Nie spodziewaliśmy się ciebie } \\
\text { tak prędko. }\end{array}$ \\
Brutus: Hatte Rückenwind. & Brutus: Dartem na kogucie. \\
\hline
\end{tabular}

W tłumaczonych na język polski dialogach tłumacz odwołał się (zdanie Dartem na kogucie.) do znanej polskiej legendy z XVI wieku przedstawiającej postać polskiego szlachcica, Pana Twardowskiego, który zaprzedał duszę diabłu. Według legendy, pewnego dnia Mistrz Twardowski, chcąc uciec przed czortem, wskoczył na koguta i wzbił się w niebo. Dodatkowo, użycie czasownika drzeć (w cytowanym kontekście darłem) wzmacnia efekt komiczny wypowiedzi. 
Podsumowując, chciałabym stwierdzić za Urbańską,

iż tłumacz dialogów w filmach dubbingowanych jest bardziej twórcą niż adaptatorem, w czym nie ma nic niestosownego, dopóki styl autorski dialogisty odpowiada swoją konwencją szerokiej publiczności (Urbańska, Siła głosu...).

W przypadku filmów dubbingowanych kluczem do sukcesu okazało się użycie potocznego języka oraz łatwe w odszyfrowaniu i śmieszące różnych odbiorców aluzje do rodzimej rzeczywistości. Ponadto, bazując na abstrakcyjnym scenariuszu, tłumacz może sobie pozwolić, bardziej niż w innych typach komunikatów audiowizualnych, na inwencję i eksperymenty językowe, ponieważ w tym przypadku liczy się efekt, a kryteria atrakcyjności i rozrywki są nadrzędne. Pochwały ze strony masowego odbiorcy oraz fakt, że publiczność wielokrotnie wybiera się na projekcję tego samego filmu, tylko potwierdzają, że zamierzony i zbieżny z oryginałem efekt komunikacyjny został osiągnięty. Podobnie jak w funkcjonalnym podejściu do przekładu również i tu tłumacz kieruje się potrzebami odbiorców docelowych i „działając jako ekspert korzysta ze znacznej (ale jednak nie nieograniczonej) swobody" (Dąbska-Prokop 2000: 234). Jego zadaniem jest przystosowanie treści tekstu do warunków kultury docelowej, które to treści może modyfikować na potrzeby konkretnej sytuacji (Nord 2009: 183).

\section{Literatura}

Belczyk, A., 2007, Tłumaczenie filmowe, Wilkowice.

Borowczyk, P., 2013, „Czynniki warunkujące popularność filmów dubbingowanych - relacje intertekstualne", [w:] Przekład jako akt komunikacji międzykulturowej, I. Kasperska, A. Żuchelkowska (red.), Poznań, s. 13-29.

Borowczyk, P., 2011 „Różne oblicza Asteriksa i zielonego ogra. Studium nad tłumaczeniem dialogów", [w:] Przekład jako produkt i kontekst jego odbioru, I. Kasperska, A. Żuchelkowska (red.), Poznań, s. 71-84.

Bukowski, P., Heydel, M. (red.), 2009, Współczesne teorie przekładu. Antologia, Kraków.

Dąbska-Prokop, U. (red.), 2000, Mała encyklopedia przekładoznawstwa, Częstochowa.

Delisle, J., Lee-Jahnke, H., Cormier, M., Tomaszkiewicz, T. (przekład i adaptacja), 2004, Terminologia tlumaczenia, Poznań. 
Garcarz, M., 2007, „Przekład slangu w filmie. Telewizyjne przekłady filmów amerykańskich na język polski”, [w:] Język a komunikacja, t. 15, J. Dybiec (red.), Kraków.

Nord, Ch., 2009, „Wprowadzenie do tłumaczenia funkcjonalnego”, [w:] Współczesne teorie przekładu. Antologia, P. Bukowski, M. Heydel (red.), Kraków.

Tomaszkiewicz, T., 2006, Przekład audiowizualny, Poznań.

Walkiewicz, B., 2013, O architekturze tekstów o architekturze $w$ perspektywie przekładu, Poznań.

Wierzbięta, B., 2004, „Zaginione w przekładzie”, wywiad Wojciecha Orlińskiego, [w:] Gazeta Wyborcza, nr 151(4665), s. 11.

Wróblewski, J., 2002, „Latać każdy może”, [w:] Polityka, nr 31(2361), s. 52-53.

Zarębski, K. J., 2001, „Zemsta jest zielona”, [w:] Kino, nr 7-8, s. 46.

\section{Strony internetowe}

Baryłkiewicz, E.A., Perspektywy pracy dla tłumaczy, http://www.translatorscafe.com/cafe/MegaBBS/thread-view.asp?threadid=4395\&messageid=174159 (dostęp: 15 października 2013 r.).

Szczypiński, A., Shrek 2 - rozszyfrowanie, http://www.film.org.pl/prace/ shrek2.html (dostęp: 15 października 2013 r.).

Urbańska, A., Dla kogo dubbingowane sa długometrażowe filmy animowane w Polsce?, http://www.dubbing.pl/index.php?option=com_content\&task=view\&id=91\&Itemid=105 (dostęp: 15 października 2013 r.).

Urbańska, A., Siła głosu tłumacza dialogów w dubbingowanych filmach animowanych http://www.dubbing.pl/index.php?option=com_content\&task=view\&id=90\&Itemid=104 (dostęp: 15 października 2013 r.).

Wierzbięta, B., (wywiad Beaty Zatońskiej), We wszystkim należy zachować umiar, http://www.tvp.info/opinie/wywiady/we-wszystkim-nalezy-zachowac-umiar (dostęp: 29 sierpnia 2013 r.).

Wierzbięta, B., (wywiad Katarzyny Długosz), Mój Shrek myśli po polsku, http://www.textum.pl/tlumaczenia/portal_tlumaczy/informacje/ogolne/artykuly/moj_shrek4.html (dostęp: 29 sierpnia 2013 r.).

Wierzbięta, B., (wywiad Katarzyny Długosz), Kojarzę się ze Shrekiem, http:// www.przeglad-tygodnik.pl/pl/artykul/kojarze-sie-ze-shrekiem (dostęp: 29 sierpnia 2013 r.).

Wierzbięta, B., (wywiad Grzegorza Wójtowicza), Na ttumaczeniu Szreka można zarobić, www.stopklatka.pl (dostęp: 29 sierpnia 2013 r.). 


\section{The Skopos theory and the role of the audiovisual translator in dubbed films}

Summary

The article focuses on the comparison of the role of the audiovisual translator in dubbed films with the role which the translator plays in the Skopos theory (German: Skopostheorie) that was established by the German linguists Hans Vermeer and Katharina Reiss; this approach propagates the functional theory of translation. Both in the Skopos theory and in dubbed films the process of translation is determined by the function of the final product. Translation is an act of intercultural mediation and thus the translator of dubbed films considers the needs of recipients and the function that a given film is to fulfill in the target culture. Localisation (adaptation), reflected in translating a variety of culture-related situations and jokes into the target language with the objective to make them contextually and culturally fitting and suitable, is applied to achieve the assumed goal in dialogue translation.

Keywords: the Skopos theory, audiovisual translation, localisation 